\title{
Detection and clinical manifestation of placental malaria in southern Ghana
}

\author{
Frank P Mockenhaupt*1, George Bedu-Addo², Christiane von Gaertner'3, \\ Renate Boyé ${ }^{1}$, Katrin Fricke ${ }^{1}$, Iris Hannibal ${ }^{1}$, Filiz Karakaya1, \\ Marieke Schaller ${ }^{1}$, Ulrike Ulmen ${ }^{1}$, Patrick A Acquah ${ }^{3}$, Ekkehart Dietz ${ }^{4}$, \\ Teunis A Eggelte ${ }^{5}$ and Ulrich Bienzle ${ }^{1}$
}

\begin{abstract}
Address: ${ }^{1}$ Institute of Tropical Medicine and International Health, Charité - University Medicine, Berlin, Germany, ${ }^{2}$ Dept. of Medicine, Komfo Anoyke Teaching Hospital, School of Medical Sciences, Kwame Nkrumah University of Science and Technology, Kumasi, Ghana, ${ }^{3}$ Presbyterian Mission Hospital, Agogo, Ghana, ${ }^{4}$ Div. of International Health, Institute of Social Medicine, Epidemiology and Health Economy, Charité -

University Medicine, Berlin, Germany and ${ }^{5}$ Division of Infectious Diseases, Tropical Medicine and AIDS, Academic Medical Centre, Amsterdam, The Netherlands

Email: Frank P Mockenhaupt* - frank.mockenhaupt@charite.de; George Bedu-Addo - gba@africaonline.com.gh; Christiane von Gaertner - cvgaertner@web.de; Renate Boyé - renate.boye@charite.de; Katrin Fricke - katrinfricke9@hotmail.com;

Iris Hannibal - iris.hannibal@med.uni-muenchen.de; Filiz Karakaya - filizkaraka@hotmail.com; Marieke Schaller - miekeschaller@yahoo.fr; Ulrike Ulmen - uulmen@web.de; Patrick A Acquah - padjeiacquah@yahoo.co.uk; Ekkehart Dietz - ekkehart.dietz@charite.de;

Teunis A Eggelte - t.a.eggelte@amc.uva.nl; Ulrich Bienzle-ulrich.bienzle@charite.de

* Corresponding author
\end{abstract}

Published: 13 December 2006

Malaria Journal 2006, 5:119 doi:10.1186/1475-2875-5-119

This article is available from: http://www.malariajournal.com/content/5///I19

(c) 2006 Mockenhaupt et al; licensee BioMed Central Ltd.

This is an Open Access article distributed under the terms of the Creative Commons Attribution License (http://creativecommons.org/licenses/by/2.0), which permits unrestricted use, distribution, and reproduction in any medium, provided the original work is properly cited.

\begin{abstract}
Background: Plasmodium falciparum can be detected by microscopy, histidine-rich-protein-2 (HRP2) capture test or PCR but the respective clinical relevance of the thereby diagnosed infections in pregnant women is not well established.

Methods: In a cross-sectional, year-round study among 839 delivering women in Agogo, Ghana, P. falciparum was screened for in both, peripheral and placental blood samples, and associations with maternal anaemia, low birth weight (LBW) and preterm delivery (PD) were analysed.

Results: In peripheral blood, P. falciparum was observed in 19\%, 34\%, and 53\% by microscopy, HRP2 test, and PCR, respectively. For placental samples, these figures were $35 \%, 41 \%$, and $59 \%$. Irrespective of diagnostic tool, P. falciparum infection increased the risk of anaemia. Positive peripheral blood results of microscopy and PCR were not associated with LBW or PD. In contrast, the HRP2 test performed well in identifying women at increased risk of poor pregnancy outcome, particularly in case of a negative peripheral blood film. Adjusting for age, parity, and antenatal visits, placental HRP2 was the only marker of infection associated with LBW (adjusted odds ratio (aOR), $1.5(95 \% \mathrm{Cl}, 1.0-2.2)$ ) and, at borderline statistical significance, PD (aOR, I.4 (I.0-2.I)) in addition to anaemia (aOR, 2.3 (I.7-3.2)). Likewise, HRP2 in peripheral blood of seemingly aparasitaemic women was associated with PD (aOR, I.7 (I.0-2.7)) and anaemia (aOR, 2.I (I.4-3.2)).

Conclusion: Peripheral blood film microscopy not only underestimates placental malaria. In this highly endemic setting, it also fails to identify malaria as a cause of foetal impairment. Sub-microscopic infections detected by a HRP2 test in seemingly aparasitaemic women increase the risks of anaemia and PD. These findings indicate that the burden of malaria in pregnancy may be even larger than thought and accentuate the need for effective anti-malarial interventions in pregnancy.
\end{abstract}




\section{Background}

Malaria in pregnancy continues to be a major public health problem in sub-Saharan Africa. Pregnant women are a specific risk group for Plasmodium falciparum infection, malaria and related consequences [1]. This increased risk is partially due to physiological alterations of immunity. Moreover, in pregnancy and by virtue of specific expression variants of the P. falciparum Erythrocyte Membrane Protein-1, parasite strains adhere to the syncytiotrophoblast, i.e. the surface lining the placental intervillous space. As immune recognition of and, thus, response to these parasites are low in primigravidae susceptibility and clinical manifestation are increased. With subsequent pregnancies, protective immune mechanisms gradually develop and expand, and manifestation of infection declines [2-4].

The placental sequestration of $P$. falciparum results in the accumulation of parasitized erythrocytes in the intervillous space, infiltration by inflammatory cells and release of pro-inflammatory mediators [5]. Clinical consequences of placental malaria, i.e. parasites and/or malaria pigment (haemozoin) present in placental blood, comprise maternal anaemia, low birth weight (LBW), preterm delivery (PD), and, consequently, increased perinatal and infant mortality [1,6-9]. In highly endemic regions, infected women are commonly asymptomatic [10]. Because of placental sequestration, peripheral blood film microscopy grossly underestimates the prevalence of placental malaria $[11,12]$.

As with malaria in children, the prevalence and manifestation of malaria in pregnancy varies with transmission intensity, access to treatment, coverage and quality of antenatal services, and drug resistance, among others. The role of sub-microscopic $P$. falciparum infections, i.e. below the threshold of peripheral blood microscopy, is not well established [10,11,13-16]. The present study aimed at assessing prevalence and clinical consequences of $P$. falciparum infections detected in peripheral and placental blood by microscopy, histidine-rich-protein-2 (HRP2) capture test, and PCR among women delivering at a district hospital in rural southern Ghana. The performances of the diagnostic tests in a subset of 596 women have been reported previously [12]. Here, results from all 839 livesingleton deliveries are reported, focusing on the clinical manifestation of malaria in pregnancy.

\section{Methods}

Agogo is a community of some 30,000 inhabitants located in the forested hills of Ashanti Akim North District. Subsistence farming, trade and mining are the main income sources in that region, and malaria is hyper- to holoenedemic [17]. In 1998, P. falciparum among women attending antenatal care at Agogo District Hospital was detected in 32\% and 63\% by microscopy and PCR assays of peripheral blood samples, respectively [10]. Then and at the time of study, chemoprophylaxis with pyrimethamine (PYR) was recommended in pregnancy; yet, P. falciparum mutations conferring PYR resistance are frequent in the area [18]. From January 2000 to January 2001, women attending Agogo Hospital for delivery were asked to participate in the present study and recruited after informed written consent was obtained. The study protocol was reviewed and approved by the Committee on Human Research Publications and Ethics, School of Medical Sciences, University of Science and Technology, Kumasi.

All women were clinically examined, socio-demographic data were documented, and venous peripheral blood collected into EDTA. Fever was defined as an axillary temperature $>37.4^{\circ} \mathrm{C}$. Following expulsion and after a small incision had been made into the maternal surface of the placenta, blood from the intervillous space was collected with a syringe containing EDTA. P. falciparum was screened for in both placental and peripheral blood samples by microscopy, HRP2 test, and PCR: malaria parasites were counted microscopically on Giemsa-stained thick blood films per 500 white blood cells for peripheral samples and per 100 high-power fields for placental samples in which the presence of leukocyte-associated haemozoin was also recorded. Based on placental thick blood film microscopy, the stage of placental infection was categorized as [5] early, only parasites visible; late, both parasites and pigment present; resolved, only pigment visible; and none, neither parasites nor haemozoin present. HRP2 was detected by rapid immuno-chromatographic tests (ICT Malaria P.f/P.v, Becton Dickinson, Germany). Following DNA extraction (QIAmp, Qiagen, Germany), nested $P$. falciparum-specific PCR assays were performed [19]. Plasma concentrations of chloroquine (CQ) and PYR were measured by ELISA assays [20] with limits of detection of $5 \mathrm{ng} / \mathrm{mL}$ and $10 \mathrm{ng} / \mathrm{mL}$, respectively. Haemoglobin $(\mathrm{Hb})$ was measured by a HemoCue photometer (Ångelholm, Sweden) and anaemia defined as $\mathrm{Hb}<11 \mathrm{~g} /$ $\mathrm{dL}$. Crude birth weight and gestational age were assessed within 24 hours after delivery. LBW was defined as a birth weight $<2500 \mathrm{~g}$ and PD as gestational age $<37$ weeks applying the Finnström score [21].

Geometric mean parasite densities (GMPDs) and 95\% confidence intervals (95\%CIs) were calculated. Continuous variables were compared between groups by t-test, analysis of variance, Mann-Whitney U test, and KruskalWallis test as applicable. Associations between P. falciparum infection and anaemia, LBW, and PD were identified by $\chi^{2}$ test, odds ratios (ORs) calculated, and adjusted for confounders by logistic regression models. 


\section{Results}

From January 2000 to January 2001, 889 delivering and consenting women were recruited and 922 babies were born (859 singles; 30 twin pairs, one set of triplets), of whom 22 (2.4\%) were born dead or died within 24 hours after delivery. The characteristics of the 839 women with live-singleton deliveries are shown in Table 1. About half of the women originated from Agogo and about half had previously attended $\leq 3$ antenatal care visits. Parity was strongly associated with LBW and PD, rates being more than double in primiparae (each, 26\%) than in multiparae (Table 1$)$. Fever was rare $(3 \%)$. PYR in plasma was detected in 35\% (median, $46 \mathrm{ng} / \mathrm{mL}$; range, 11-1000) and CQ in $22 \%$ (median, $31 \mathrm{ng} / \mathrm{mL}$; range, 6-1248).

\section{Detection and prevalence of Plasmodium falciparum}

In all 839 peripheral samples, $P$. falciparum was detected in $19.0 \%, 34.1 \%$, and $52.9 \%$ by microscopy, HRP2 test, and PCR, respectively. For placental samples, these figures were $34.9 \%, 40.8 \%$, and 59.4\%; placental haemozoin was seen in $30.9 \%$. As reported before [12], sensitivity of peripheral blood film microscopy in detecting placental infection was poor. It was 50\% (95\%CI, 44-59) and 32\% (56-63) taking the results of placental microscopy and PCR assays, respectively, as reference (specificities, 98\%
(96-99) and 100\% (99-100)). For HRP2 tests on peripheral blood samples, these sensitivities were 78\% (73-82; specificity, 89\% (86-92)) and 56\% (51-60; specificity, $98 \%$ (95-99)). PCR assays on peripheral samples achieved a sensitivity of 97\% (94-99; specificity, 71\% (69-75)) for microscopically confirmed placental parasitaemia and of 87\% (83-89; specificity, 96\% (93-98)) with PCR-proven placental infection as reference. Irrespective of diagnostic technique, $P$. falciparum declined in prevalence with parity as did placental parasite density (Table 2). Also, the presence of haemozoin decreased with parity and, consequently, late infections predominated in primiparae and early infections in multiparae (Table 2). Non-falciparum species were rare (six Plasmodium malariae, five Plasmodium ovale) and not related to parity.

\section{Factors influencing the presence of placental malaria}

Placental haemozoin was the clinically most relevant marker of infection and factors influencing its presence were analysed. In multivariate analysis, primiparity, low age, and delivery in the rainy season were independently associated with haemozoin (Table 3 ). In women with $>3$ antenatal care visits, haemozoin was somewhat less common $(28.2 \%, 121 / 429)$ than in women with fewer visits $(33.7 \%, 132 / 392 ; P=0.09)$. PYR in plasma was associated

Table I: Characteristics of 839 women with live singleton deliveries

\begin{tabular}{|c|c|c|c|c|c|}
\hline Parameter & All & Primiparae & Parae II \& III & Multiparae (>III) & $P$ \\
\hline No. (\%) & $839(100)$ & $304 / 832(36.5)$ & $305 / 832(36.7)$ & $223 / 832(26.8)$ & \\
\hline Age (years; median, range; $n=827$ ) & $25(15-47)$ & $21(15-36)$ & $25(18-40)^{*}$ & $33(22-47)^{*}$ & $<0.0001$ \\
\hline Residence in Agogo (\%, No.) & $48.9(410)$ & $48.7(148 / 304)$ & $54.8(167 / 305)$ & $41.3(92 / 223)$ & 0.009 \\
\hline Proportion without school degree (\%, No.) & $15.4(128 / 829)$ & $8.6(26 / 302)$ & $14.6(44 / 302)^{*}$ & $26.0(57 / 219)^{*}$ & $<0.0001$ \\
\hline Axillary temperature $\left({ }^{\circ} \mathrm{C} ;\right.$ mean $\left.\pm \mathrm{SD} ; n=826\right)$ & $36.4 \pm 0.5$ & $36.5 \pm 0.6$ & $36.4 \pm 0.5$ & $36.4 \pm 0.5$ & 0.32 \\
\hline Fever (\%, No.) & $2.8(23 / 826)$ & $4.0(12 / 300)$ & $1.7(5 / 302)$ & $2.7(6 / 129)$ & 0.22 \\
\hline Haemoglobin (g/dL; median; range) & II.5 (4.6-16.8) & II.4 (4.6-16.4) & II.6 (5.8-16.8) & II.5 (4.7-I5.6) & 0.28 \\
\hline Anaemia (haemoglobin <II g/dL) & $35.2(295)$ & $38.5(117 / 304)$ & $32.5(99 / 305)$ & $35.0(78 / 223)$ & 0.30 \\
\hline No. of previous ANC visits (median, range, $n=82 \mathrm{I}$ ) & $4(0-12)$ & $3(0-I I)$ & $4(0-12)^{*}$ & $4(0-10)$ & 0.01 \\
\hline Proportion with $\leq 3$ ANC visits (\%, No.) & $47.7(392 / 821)$ & $52.5(156 / 297)$ & $43.1(129 / 299)^{*}$ & $47.9(105 / 219)$ & 0.07 \\
\hline Caesarean section (\%, No.) & $22.1(185)$ & $21.7(66 / 304)$ & $19.0(58 / 305)$ & $26.5(59 / 223)$ & 0.12 \\
\hline Birth weight (g; median, range; $n=838$ ) & $2950(1280-4500)$ & $2785(1280-4000)$ & $3000(1600-4250)^{*}$ & $3100(1500-4500)^{*}$ & $<0.0001$ \\
\hline Gestational age (weeks; median, range; $n=83 \mathrm{I}$ ) & $38.4(20.0-43.1)$ & $38.4(20.0-43.1)$ & $39.0(32.0-43.1)^{*}$ & $39.4(27.0-42.1)^{*}$ & 0.0001 \\
\hline Low birth weight (LBW) & $16.0(134 / 837)$ & $26.0(79 / 304)$ & $10.9(33 / 304)^{*}$ & $9.4(21 / 223)^{*}$ & $<0.0001$ \\
\hline Preterm delivery & $18.8(156 / 83 \mid)$ & $26.3(80 / 304)$ & $16.0(48 / 300)^{*}$ & $12.2(27 / 221)^{*}$ & $<0.0001$ \\
\hline Proportion with chloroquine in plasma (\%, No.) & $22.4(182 / 82 \mid)$ & $27.9(83 / 298)$ & I9.I (57/299)* & $19.4(42 / 217)^{*}$ & 0.02 \\
\hline Proportion with pyrimethamine in plasma (\%, No.) & $35.0(287 / 821)$ & $35.6(106 / 298)$ & $33.8(101 / 299)$ & $35.9(78 / 217)$ & 0.85 \\
\hline
\end{tabular}

*, difference to primiparae, $P<0.05 ;$ ANC, antenatal care 
Table 2: Prevalence of Plasmodium falciparum in 832 delivering women according to parity

\begin{tabular}{|c|c|c|c|c|}
\hline \multirow[t]{2}{*}{ Parameter } & \multicolumn{3}{|c|}{ Prevalence of Plasmodium falciparum (\%) } & \multirow[t]{2}{*}{$P$} \\
\hline & Primiparae & Parae II \& III & Multiparae & \\
\hline No. & 304 & 305 & 223 & \\
\hline \multicolumn{5}{|l|}{ Peripheral blood } \\
\hline \multicolumn{5}{|l|}{ Diagnosic mean } \\
\hline Microscopy & 27.0 & $16.4 *$ & $11.7 *$ & $<0.0001$ \\
\hline HRP2 test & 45.4 & $30.5^{*}$ & $23.8 *$ & $<0.0001$ \\
\hline PCR & 59.2 & 52.1 & $46.2^{*}$ & 0.01 \\
\hline GMPD $(\mu \mathrm{L}, 95 \% \mathrm{Cl})$ & $740(48|-| 137)$ & $343(189-623)^{*}$ & $593(263-1336)$ & 0.12 \\
\hline \multicolumn{5}{|l|}{ Placental blood } \\
\hline \multicolumn{5}{|l|}{ Diagnostic mean } \\
\hline Microscopy & 46.1 & $33.1 *$ & $22.0 *$ & $<0.0001$ \\
\hline Haemozoin & 42.4 & $29.8 *$ & $16.6 *$ & $<0.0001$ \\
\hline HRP2 test & 50.7 & $37.4^{*}$ & $32.3^{*}$ & $<0.0001$ \\
\hline PCR & 65.1 & 59.7 & $52.0 *$ & 0.01 \\
\hline GMPD (/HPF; 95\%Cl) & $1.2(0.8-1.8)$ & $0.6(0.4-1.1)$ & $0.4(0.2-0.7)^{*}$ & 0.01 \\
\hline \multicolumn{5}{|l|}{ Stage of infection } \\
\hline None & 47.4 & $57.7 *$ & $70.9 *$ & \\
\hline Resolved & 6.6 & 9.2 & 7.2 & \\
\hline Late & 35.9 & $20.7 *$ & $9.4^{*}$ & \\
\hline Early & 10.2 & 12.5 & 12.6 & $<0.0001$ \\
\hline
\end{tabular}

HRP2, histidine-rich-protein 2; GMPD, geometric mean parasite density; $95 \% \mathrm{Cl}, 95 \%$ confidence interval; HPF, high power field; *, difference to primiparae, $P<0.05$

Table 3: Risk factors of placental haemozoin

\begin{tabular}{|c|c|c|c|c|c|}
\hline \multirow[t]{2}{*}{ Factor } & \multirow[t]{2}{*}{ Haemozoin detected (\%, fraction) } & \multicolumn{2}{|c|}{ Univariate analysis } & \multicolumn{2}{|c|}{ Multivariate analysis } \\
\hline & & OR $(95 \% \mathrm{Cl})$ & $P$ & OR $(95 \% \mathrm{Cl})$ & $P$ \\
\hline \multicolumn{6}{|l|}{ Parity } \\
\hline$>1$ & $24.2(128 / 528)$ & I & & I & \\
\hline 1 & $42.4(129 / 304)$ & $2.3(1.7-3.2)$ & $<0.0001$ & I.5 (I.0-2.2) & 0.04 \\
\hline \multicolumn{6}{|c|}{ Age-group (years) } \\
\hline$>30$ & $17.4(33 / 190)$ & 1 & & 1 & \\
\hline $26-30$ & $27.0(57 / 211)$ & $1.8(1.1-2.9)$ & 0.02 & I.7 (I.0-2.8) & 0.04 \\
\hline $21-25$ & $33.9(82 / 242)$ & $2.4(1.5-4.0)$ & 0.0001 & $2.1(1.3-3.5)$ & 0.003 \\
\hline$\leq 20$ & $45.7(84 / 184)$ & $4.0(2.4-6.6)$ & $<0.0001$ & $3.0(1.7-5.2)$ & 0.0002 \\
\hline \multicolumn{6}{|l|}{ Season } \\
\hline Dry & $27.1(109 / 402)$ & I & & 1 & \\
\hline Rainy* & $34.3(150 / 437)$ & $1.4(1.0-1.9)$ & 0.02 & $1.4(1.1-2.0)$ & 0.02 \\
\hline
\end{tabular}

OR, odds ratio: $95 \% \mathrm{Cl}, 95 \%$ confidence interval; *, rainy season, May-October 
with a slight reduction in the prevalence of haemozoin only $(27.9 \%, 80 / 287$ vs. $32.4 \%, 173 / 534 ; P=0.18)$. In primiparae, this difference was pronounced and statistically significant $(31.1 \%, 33 / 106$ vs. $47.9 \%, 92 / 192 ; P=$ 0.005).

\section{Association between diagnosis of malaria and its clinical manifestation}

Irrespective of diagnostic tool, $P$. falciparum infection increased the risk of maternal anaemia (Table 4). A positive peripheral blood film or a positive PCR result were neither associated with LBW nor with PD. In peripheral blood samples, the HRP2 test best discriminated women with and without malaria-associated adverse foetal outcome (Table 4). Importantly, in women with a negative peripheral blood film, a positive HRP2 test indicated risk increases of 71\%, 79\%, and $114 \%$ for LBW, PD, and anaemia, respectively. A positive PCR signal in this sub-group was associated only with anaemia. Further stratification revealed that in case of a positive peripheral result exclusively by PCR $(n=160)$, the proportions of LBW $(15 \%)$ and PD (14\%) were similar to the figures in de facto noninfected women $(n=382 ; 14 \%, P=0.7 ;$ and $17 \%, P=$ $0.4)$. Still, the prevalence of anaemia was increased $(39 \%$ vs. $25 \%, P=0.002)$.

Peripheral blood parasite densities (GMPD, 558/ $\mu \mathrm{L}$; 95\%CI, 404-772) correlated negatively with $\mathrm{Hb}\left(\log _{10}\right.$ parasite density, $\mathrm{r}=-0.18, P=0.02)$ and gestational week ( $\mathrm{r}=-0.18, P=0.03)$ but not with birth weight $(\mathrm{r}=-0.06$; $P=0.5$ ). Placental parasite density (GMPD, 0.78/high power field; $95 \% \mathrm{CI}, 0.06-1.03$ ) did not show such correlations.

On the basis of placental sampling, again, microscopic and PCR detection of parasitaemia were not associated with LBW or PD whereas a positive HRP2 result was. Nevertheless, haemozoin was the marker of infection most strongly associated with all clinical consequences (Table 4). Likewise, late infections were found to be the most deleterious ones while patients with early infections clinically were similar to non-infected women. Haemozoin was also associated with the largest reduction in birth weight (median, $2850 \mathrm{~g}$ (range, 1280-4160) vs. $3000 \mathrm{~g}$ (1420-4500), $P<0.0001)$ which was smaller in case of a positive HRP2 test (2880 g (1420-4160) vs. 3000 (1280$4500), P=0.0009$ ) or a positive PCR result (2900 (12804350) vs. $3000 \mathrm{~g}(1500-4500), P=0.04)$, and smallest if placental parasites were seen by microscopy (2900 g (1280-4160) vs. $2970 \mathrm{~g}(1420-4500), P=0.02)$. Likewise, any diagnosis of placental $P$. falciparum was associated with significantly reduced $\mathrm{Hb}$ levels, but the reduction was largest in the presence of haemozoin (median, $10.8 \mathrm{~g} / \mathrm{dL}$ (range, 4.6-15.6) vs. $11.7 \mathrm{~g} / \mathrm{dL}$ (4.716.8), $P<0.0001)$. The week of gestation was not associ- ated with infection, irrespective of diagnostic mean applied (data not shown).

Adjusting the above associations between $P$. falciparum infection and clinical manifestation for the confounders age, parity, and number of antenatal care visits did not substantially change the findings, however, statistical significance in terms of LBW and PD was reduced (Table 5).

\section{Discussion}

Placental malaria is an important cause of both LBW and PD, which, in turn, are major determinants of neonatal and infant mortality [22-24]. Annually, up to 200,000 infant deaths are attributed to malaria in pregnancy [25]. However, malaria in pregnancy frequently lacks overt clinical signs and its diagnosis is complicated by placental parasite sequestration.

In the present study, the vast majority of $P$. falciparuminfected delivering women were asymptomatic, and microscopy of thick films from peripheral blood missed more current infections than it detected. Roughly half of the women with microscopically proven placental parasitaemia had a negative peripheral blood film. The observed superior sensitivities of peripheral blood PCR or HRP2 assays are essentially in accord with previous reports $[11,14,26,27]$ and underscore that a negative peripheral blood film in pregnant women in endemic areas is hardly informative. In addition, the present study shows that in contrast to peripheral blood microscopy and PCR, HRP2 detection indicates an increased risk of poor pregnancy outcome and that sub-microscopic infections in pregnancy are associated with maternal and foetal morbidity.

Placental histology is considered the "gold standard" of malaria diagnosis in pregnancy for epidemiological or study purposes, however, due to limited technical expertise it is rarely available in endemic areas. Examination of thick films of blood samples obtained by placental incision is comparatively easier. As compared to histology, sensitivity and specificity of this method have been reported to be $76 \%$ and $99 \%$, respectively, and thus to be in the range of microscopy of blood films produced by scraping the wall of the incision or by spinning down erythrocyte pellets from biopsy washings [28]. The detection of haemozoin on placental thick blood films likely is influenced by this difference in sensitivity and also neglects pigment deposition in placental structures. Consequently, staging placental infection based on placental thick blood films findings [5] - although deduced from the histological classification after Bulmer et al. [29] - is not fully comparable to histology and needs further evaluation. Nevertheless, haemozoin may be considered a "black box" in recording episodes of malaria in pregnancy even though the time span during which pigment can be 
Table 4: Prevalences of low birth weight, preterm delivery, and maternal anaemia according to diagnosis of Plasmodium falciparum

\begin{tabular}{|c|c|c|c|c|c|c|c|c|c|c|}
\hline \multirow[t]{2}{*}{ Diagnostic tool } & \multirow[t]{2}{*}{ No. } & \multicolumn{3}{|c|}{ Low birth weight } & \multicolumn{3}{|c|}{ Preterm delivery } & \multicolumn{3}{|c|}{ Anaemia } \\
\hline & & $\%$ & OR $(95 \% \mathrm{Cl})$ & $P$ & $\%$ & OR $(95 \% \mathrm{Cl})$ & $P$ & $\%$ & OR $(95 \% \mathrm{Cl})$ & $P$ \\
\hline \multicolumn{11}{|c|}{ Peripheral blood } \\
\hline \multicolumn{11}{|l|}{ Microscopy } \\
\hline Negative & 680 & 15.8 & & & 18.4 & & & 32.9 & & \\
\hline Positive & 159 & 17.0 & I.I (0.7-I.8) & ns & 20.3 & I.I (0.7-I.8) & ns & 44.7 & $1.6(1.1-2.4)$ & 0.005 \\
\hline \multicolumn{11}{|l|}{ HRP2 test } \\
\hline Negative & 553 & 14.3 & & & 16.5 & & & 29.5 & & \\
\hline Positive & 286 & 19.4 & $1.4(1.0-2.1)$ & 0.06 & 23.1 & $1.5(1 . I-2.2)$ & 0.02 & 46.2 & $2.1(1.5-2.8)$ & $<0.0001$ \\
\hline \multicolumn{11}{|l|}{ PCR } \\
\hline Negative & 395 & 14.2 & & & 17.9 & & & 25.6 & & \\
\hline Positive & 444 & 17.6 & $1.3(0.9-1.9)$ & ns & 19.6 & I.I (0.8-I.6) & ns & 43.7 & $2.3(1.7-3.1)$ & $<0.0001$ \\
\hline \multicolumn{11}{|c|}{ HRP2 test if microscopy negative } \\
\hline Negative & 542 & 14.2 & & & 16.5 & & & 29.3 & & \\
\hline Positive & 138 & 21.9 & $1.7(1.0-2.8)$ & 0.03 & 26.1 & $1.8(1.1-2.9)$ & 0.01 & 47.1 & $2.1(1.4-3.2)$ & $<0.0001$ \\
\hline \multicolumn{11}{|c|}{ PCR if microscopy negative } \\
\hline Negative & 394 & 14.2 & & & 17.9 & & & 25.6 & & \\
\hline Positive & 286 & 17.9 & $1.3(0.9-2.0)$ & ns & 19.1 & I.I (0.7-I.6) & ns & 43.0 & $2.2(1.6-3.1)$ & $<0.0001$ \\
\hline \multicolumn{11}{|l|}{ Placental blood } \\
\hline \multicolumn{11}{|l|}{ Microscopy } \\
\hline Negative & 546 & 14.3 & & & 17.7 & & & 28.8 & & \\
\hline Positive & 293 & 19.2 & $1.4(1.0-2.1)$ & 0.07 & 20.8 & $1.2(0.8-1.8)$ & ns & 47.1 & $2.2(1.6-3.0)$ & $<0.0001$ \\
\hline \multicolumn{11}{|l|}{ Haemozoin } \\
\hline Negative & 580 & 13.6 & & & 16.5 & & & 27.8 & & \\
\hline Positive & 259 & 21.3 & $1.7(1.2-2.6)$ & 0.005 & 23.9 & $1.6(1.1-2.3)$ & 0.01 & 51.7 & $2.8(2.0-3.8)$ & $<0.0001$ \\
\hline \multicolumn{11}{|l|}{ HRP2 test } \\
\hline Negative & 497 & 12.9 & & & 16.0 & & & 27.0 & & \\
\hline Positive & 342 & 20.5 & I.8 (1.2-2.6) & 0.003 & 22.8 & $1.6(1.1-2.2)$ & 0.01 & 47.1 & $2.4(1.8-3.3)$ & $<0.0001$ \\
\hline \multicolumn{11}{|l|}{ PCR } \\
\hline Negative & 341 & 13.5 & & & 17.5 & & & 23.8 & & \\
\hline Positive & 498 & 17.7 & $1.4(0.9-2.1)$ & ns & 19.7 & I.2 (0.8-I.7) & ns & 43.0 & $2.4(1.8-3.3)$ & $<0.0001$ \\
\hline \multicolumn{11}{|l|}{ Stage of infection } \\
\hline None & 482 & 13.5 & & & 16.7 & & & 27.0 & & \\
\hline Resolved & 64 & 20.3 & $1.6(0.8-3.3)$ & ns & 25.0 & $1.7(0.9-3.2)$ & ns & 42.2 & $2.0(1.1-3.5)$ & 0.01 \\
\hline Late & 195 & 21.6 & I.8 (I.I-2.8) & 0.009 & 23.6 & $1.5(1.0-2.4)$ & 0.04 & 54.9 & $3.3(2.3-4.7)$ & $<0.0001$ \\
\hline Early & 98 & 14.3 & I.I (0.6-2.I) & ns & 15.5 & $0.9(0.5-1.7)$ & ns & 31.6 & I.3 (0.8-2.1) & ns \\
\hline
\end{tabular}

OR, odds ratio, $95 \% \mathrm{Cl}, 95 \%$ confidence interval; ns, not significant, $P>0.1$ 
Table 5: Adjusted risk estimates for low birth weight, preterm delivery, and maternal anaemia according to diagnosis of Plasmodium falciparum

\begin{tabular}{|c|c|c|c|c|c|c|}
\hline \multirow[t]{2}{*}{ Positive diagnosis } & \multicolumn{2}{|c|}{ Low birth weight } & \multicolumn{2}{|c|}{ Preterm delivery } & \multicolumn{2}{|c|}{ Anaemia } \\
\hline & $\mathrm{aOR}(95 \% \mathrm{Cl})$ & $P$ & $\mathrm{aOR}(95 \% \mathrm{Cl})$ & $P$ & aOR $(95 \% \mathrm{Cl})$ & $P$ \\
\hline \multicolumn{7}{|l|}{ Peripheral blood } \\
\hline Microscopy & $0.9(0.6-1.5)$ & ns & I.I (0.7-I.7) & ns & $1.6(1.1-2.3)$ & 0.01 \\
\hline HRP2 test & $1.2(0.8-1.8)$ & ns & $1.4(0.9-2.0)$ & ns & $2.0(1.5-2.7)$ & $<0.0001$ \\
\hline PCR & I.I (0.8-1.7) & ns & I.I (0.7-1.5) & ns & $2.1(1.6-2.9)$ & $<0.0001$ \\
\hline HRP2 test if microscopy negative & $1.5(0.9-2.5)$ & ns & $1.7(1.0-2.7)$ & 0.03 & $2.1(1.4-3.2)$ & 0.0002 \\
\hline PCR if microscopy negative & $1.2(0.8-1.9)$ & ns & $1.0(0.7-1.6)$ & ns & $2.0(1.4-2.8)$ & $<0.0001$ \\
\hline \multicolumn{7}{|l|}{ Placental blood } \\
\hline Microscopy & I.I (0.7-I.7) & ns & I.I (0.7-I.6) & ns & $2.2(1.6-2.9)$ & $<0.0001$ \\
\hline Haemozoin & $1.3(0.8-1.9)$ & ns & $1.3(0.9-1.9)$ & ns & $2.8(2.0-3.9)$ & $<0.0001$ \\
\hline HRP2 test & $1.5(1.0-2.2)$ & 0.04 & $1.4(1.0-2.1)$ & 0.055 & $2.3(1.7-3.2)$ & $<0.0001$ \\
\hline PCR & $1.2(0.8-1.9)$ & ns & I.I (0.8-1.6) & ns & $2.4(1.7-3.3)$ & $<0.0001$ \\
\hline \multicolumn{7}{|l|}{ Stage of infection } \\
\hline Resolved & I.5 (0.8-3.0) & ns & $1.5(0.8-2.9)$ & ns & $2.0(1.1-3.4)$ & 0.02 \\
\hline Late & $1.2(0.8-1.9)$ & ns & $1.2(0.8-1.9)$ & ns & $3.4(2.3-4.9)$ & $<0.0001$ \\
\hline Early & I.I $(0.6-2.1)$ & ns & $1.0(0.5-1.8)$ & ns & $1.2(0.8-2.0)$ & ns \\
\hline
\end{tabular}

aOR, adjusted odds ratio, $95 \% \mathrm{Cl}, 95 \%$ confidence interval; ns, not significant, $P>0.1$. Odds ratios are adjusted for age (years), parity (log 10 ), and antenatal care $(\leq,>3$ visits).

found after resolved infection is unknown. In Thailand, placental haemozoin was observed among women with preceding malaria during the first trimester [30] but in Malawi, haemozoin concentrations were not elevated in women who had infections early in pregnancy [31]. For clinical use, haemozoin detection is practically unhelpful as it can be performed only at delivery, however, for epidemiological and intervention studies, it appears feasible and cost-effective.

The sensitivities of the HRP2 test (78\%) or PCR (97\%) in detecting microscopically proven placental parasitaemia in peripheral blood were substantially higher than the one of peripheral blood film microscopy (50\%). Improving performances of the peripheral blood tests with increasing placental parasite density have been described previously [12]. Because P. falciparum secretes HRP2, this protein can be detected in peripheral blood despite placental sequestration. In the present study, the specificities of the HRP2 test and of PCR were rather low when placental parasitaemia was taken as the reference. However, this probably is due to undetected parasites: when a positive placental PCR result was set as reference, specificities of HRP2 test and PCR on peripheral blood samples approached $100 \%$. Similarily, the few studies comparing histology to PCR indicate a specificity of the latter of $100 \%[32,33]$. Nevertheless, it should be kept in mind that PCR assays can remain positive for some days after curative treatment (and HRP2 tests for some weeks) [34,35].

Poor pregnancy outcome, e.g. LBW or PD, in this crosssectional study at delivery was neither associated with a positive peripheral blood result of microscopy nor of
PCR. This may be explained by the low sensitivity of the former, and the very high one of the latter. The HRP2 test with in-between sensitivity appears to be a practical compromise between sensitivity on the one hand and detecting clinically relevant infection on the other. Importantly, in seemingly aparasitaemic women, i.e. in those with a negative peripheral blood film, a positive HRP2 test was associated with anaemia, LBW and PD. Infections detected beyond that exclusively by PCR had no discernible effect on pregnancy outcome but were still associated with reduced maternal $\mathrm{Hb}$. Previous studies on that topic produced conflicting results: in Ghana but not in Sudan, Mozambique, and Cameroon, sub-microscopic peripheral blood infections as detected by PCR were associated with low Hb levels or anaemia $[10,13,15,16]$. Similar to the findings of the present study, $P$. falciparum as identified by peripheral blood microscopy or PCR in Burkina Faso was not associated with LBW or birth weight whereas the latter was reduced in case of a positive peripheral blood HRP2 dipstick [14]. Women found to be P. falciparum positive by PCR exclusively exhibited no increased risk of LBW in Malawi [11]. One study from Kenya reported that malaria as assessed by peripheral blood film was stronger associated with intrauterine growth retardation than were peripheral PCR or detection of circulating parasite antigen [36]. Differing results in these studies may be due to sample sizes, endemicity, and techniques applied. Taken together, one conclusion could be that PCR assays also detect low-level infections which produce no major foetal impairment. However, this interpretation needs caution as the course of sub-microscopic $P$. falciparum infection in pregnancy, e.g. abortive, chronic or progressive, is unknown. Considering the common fluc- 
tuations of parasite density [37], the temporal pattern of the manifestation of malaria in pregnancy [7] and the results presented here any infection detected should be considered potentially harmful (and treated). Even submicroscopic infections detected exclusively by PCR were associated with maternal anaemia which may impair physical performance and increase the risk of PD [38].

The detection of haemozoin and placental HRP2 to similar extents were univariately associated with anaemia, LBW and PD but the reductions of $\mathrm{Hb}$ and birth weight were most pronounced in women with placental pigment. The association between placental haemozoin and LBW is well documented, e.g. in Senegal [39]. In contrast, in Malawi, haemozoin concentrations were neither associated with PD nor with intrauterine growth retardation [31], and in Tanzania, the role of placental pigment in LBW and PD waned when considering mononuclear placental infiltration and high peripheral parasite density, respectively [8]. The latter authors argued that haemozoin rather reflects the severity of a recent infection than having direct detrimental effects on foetal growth. However, haemozoin concentrations have been reported to correlate with the placental expression of tumour necrosis factor [40], and recent investigations indicate that pigment is not inert but exhibits direct clinical effects [41].

After adjusting for age, parity, and antenatal visits, the risk of maternal anaemia remained to be increased in the presence of $P$. falciparum, irrespective of diagnostic tool. However, in terms of placental diagnosis, only HRP2 was associated with LBW and PD, the latter at borderline statistical significance. Also, seemingly aparasitaemic women with HRP2 in peripheral blood exhibited an increased risk of PD. Infection detected by microscopy or PCR were not correlated with birth outcome. This unexpected but not uncommon finding $[6,7,42]$ may reflect the importance of the temporal pattern of infection [7] and the greater contribution of various other factors to adverse foetal outcome. For instance, HIV infection, malnutrition, genetic traits, smoking, and a low socio-economic status are risk factors for poor pregnancy outcome [43-45] but these factors were either not assessed or were rare. Recent data indicate a median HIV prevalence of $2.7 \%$ among antenatal care attendees in Ghana [46]. Still, malaria may effect poor pregnancy outcome indirectly via maternal anaemia $[38,47]$.

The effects of antenatal care and of PYR in plasma were modest in that infection was not consistently prevented by either factor. Reasons for the limited impact of PYR chemoprophylaxis likely include poor compliance (only $35 \%$ of the women had detectable PYR) and drug resistance. Already in $1998,81 \%$ and $36 \%$ of $P$. falciparum isolated from pregnant women in Agogo exhibited a dihydrofolate reductase resistance core mutation and the high resistance triple mutation, respectively [18]. From 2005 on, intermittent preventive treatment (IPT) with sulfadoxine-pyrimethamine is operative at Agogo Hospital, and results from a survey in pregnancy in 2006 are being awaited. Optimistically, with extended antenatal services and coverage, and IPT, a reduction in the burden of malaria in pregnancy in this area should be achievable.

\section{Conclusion}

In conclusion, placental malaria commonly is missed by standard microscopy of peripheral blood films. Whereas positive results of PCR seem not to be related to poor pregnancy outcome, detection of HRP2 is capable of identifying $P$. falciparum infections associated with maternal and foetal morbidity. This is particularly true for women with a negative peripheral blood film. These findings are of importance for the implementation and evaluation of preventive measures for pregnant women in endemic areas and likely also for the assessment of response to treatment. The incorporation of sensitive rapid test devices such as HRP2 tests into antenatal services would be desirable. So far, the costs of IPT with SP are lower than the price of a dipstick of $€ 1$ ore more. However, cost-benefit considerations may change once SP has to be replaced because of intensifying drug resistance by more expensive drugs. In an operational sense, a dipstick in the second and third trimester may identify women in whom antimalarial interventions failed and who are at increased risk of maternal and foetal morbidity.

\section{Authors' contributions}

FPM, GBA, and UB designed the study. CvG, RB, KF, IH, FK, MS, UU, FPM and PAA were responsible for patient recruitment, and clinical and parasitological examinations. ED and FPM did the statistical analyses; TAE measured drug concentrations. FPM wrote the paper with major contributions of the other authors.

\section{Acknowledgements}

We thank the mothers who participated in this study and the midwifes at Agogo Hospital. This study was supported by Charité (grants 99-640, 2000-5 I2, 200I-6I3), MerkSharpDome, Germany (grant "Infectious Diseases 1999"), and Becton Dickinson (donation of ICT Malaria P.f/P.v tests) and forms part of the doctoral theses of RB, KF, IH, and MS.

\section{References}

I. Brabin BJ: An analysis of malaria in pregnancy in Africa. Bull World Health Organ 1983, 61:1005-1016.

2. Fried M, Nosten F, Brockman A, Brabin BJ, Duffy PE: Maternal antibodies block malaria. Nature I998, 395:85I-852.

3. Duffy PE, Fried M: Antibodies that inhibit Plasmodium falciparum adhesion to chondroitin sulfate $A$ are associated with increased birth weight and the gestational age of newborns. Infect Immun 2003, 7 I:6620-6623.

4. Brabin BJ, Romagosa C, Abdelgalil S, Menendez C, Verhoeff FH, McGready R, Fletcher KA, Owens S, D'Alessandro U, Nosten F, Fischer PR, Ordi J: The sick placenta-the role of malaria. Placenta 2004, 25:359-378. 
5. Fried M, Muga RO, Misore AO, Duffy PE: Malaria elicits type cytokines in the human placenta: IFN-gamma and TNFalpha associated with pregnancy outcomes. J Immunol 1998 , 160:2523-2530.

6. Steketee RW, Wirima JJ, Hightower AW, Slutsker L, Heymann DL, Breman JG: The effect of malaria and malaria prevention in pregnancy on offspring birthweight, prematurity, and intrauterine growth retardation in rural Malawi. Am J Trop Med Hyg 1996, 55(I Suppl):33-4|

7. Sullivan AD, Nyirenda T, Cullinan T, Taylor T, Harlow SD, James SA Meshnick SR: Malaria infection during pregnancy: intrauterine growth retardation and preterm delivery in Malawi. J Infect Dis 1999, 179:1580-1583.

8. Menendez C, Ordi J, Ismail MR, Ventura PJ, Aponte JJ, Kahigwa E, Font $\mathrm{F}$, Alonso PL: The impact of placental malaria on gestational age and birth weight. J Infect Dis 2000, 18 I:1740-1745.

9. van Geertruyden JP, Thomas F, Erhart A, D'Alessandro U: The contribution of malaria in pregnancy to perinatal mortality. Am J Trop Med Hyg 2004, 7 I (2 Suppl):35-40.

10. Mockenhaupt FP, Rong B, Till H, Eggelte TA, Beck S, Gyasi-Sarpong C, Thompson WN, Bienzle U: Submicroscopic Plasmodium falciparum infections in pregnancy in Ghana. Trop Med Int Health 2000, 5:167-173.

II. Mankhambo L, Kanjala M, Rudman S, Lema VM, Rogerson SJ: Evaluation of the OptiMAL rapid antigen test and species-specific PCR to detect placental Plasmodium falciparum infection at delivery. J Clin Microbiol 2002, 40:I55-I58.

12. Mockenhaupt FP, Ulmen U, von Gaertner C, Bedu-Addo G, Bienzle U: Diagnosis of placental malaria. J Clin Microbiol 2002, 40:306-308.

13. Saute F, Menendez C, Mayor A, Aponte J, Gomez-Olive X, Dgedge M, Alonso $P$ : Malaria in pregnancy in rural Mozambique: the role of parity, submicroscopic and multiple Plasmodium falciparum infections. Trop Med Int Health 2002, 7:19-28.

14. Singer LM, Newman RD, Diarra A, Moran AC, Huber CS, Stennies G, Sirima SB, Konate A, Yameogo M, Sawadogo R, Barnwell JW, Parise ME: Evaluation of a malaria rapid diagnostic test for assessing the burden of malaria during pregnancy. Am J Trop Med Hyg 2004, 70:48I-485.

15. Adam I, A-Elbasit IE, Salih I, Elbashir MI: Submicroscopic Plasmodium falciparum infections during pregnancy, in an area of Sudan with a low intensity of malaria transmission. Ann Trop Med Parasitol 2005, 99:339-344.

16. Walker-Abbey A, Djokam RR, Eno A, Leke RF, Titanji VP, Fogako J, Sama G, Thuita LH, Beardslee E, Snounou G, Zhou A, Taylor DW: Malaria in pregnant Cameroonian women: the effect of age and gravidity on submicroscopic and mixed-species infections and multiple parasite genotypes. Am J Trop Med Hyg 2005, 72:229-235.

17. Browne EN, Frimpong E, Sievertsen J, Hagen J, Hamelmann C, Dietz K, Horstmann RD, Burchard GD: Malariometric update for the rainforest and savanna of Ashanti region, Ghana. Ann Trop Med Parasitol 2000, 94:15-22.

18. Mockenhaupt FP, Eggelte TA, Böhme T, Thompson WN, Bienzle U: Plasmodium falciparum dihydrofolate reductase alleles and pyrimethamine use in pregnant Ghanaian women. Am J Trop Med Hyg 200I, 65:2I-26.

19. Snounou G, Viriyakosol S, Zhu XP, Jarra W, Pinheiro L, do Rosario VE, Thaithong S, Brown KN: High sensitivity of detection of human malaria parasites by the use of nested polymerase chain reaction. Mol Biochem Parasitol I993, 61:315-320.

20. Witte AM, Klever HJ, Brabin BJ, Eggelte TA, Van der Kaay HJ, Alpers MP: Field evaluation of the use of an ELISA to detect chloroquine and its metabolites in blood, urine and breast-milk. Trans R Soc Trop Med Hyg 1990, 84:521-525.

21 . Finnström O: Studies on maturity in newborn infants. IX. Further observations on the use of external characteristics in estimating gestational age. Acta Paediatr Scand 1977, 66:60 I-604.

22. McCormick MC: The contribution of low birth weight to infant mortality and childhood morbidity. N Engl J Med 1985, 3 | 2:82-90

23. Kramer MS: Determinants of low birth weight: methodological assessment and meta-analysis. Bull World Health Organ 1987, 65:663-737.

24. Kramer MS, Demissie K, Yang H, Platt RW, Sauve R, Liston R: The contribution of mild and moderate preterm birth to infant mortality. Fetal and Infant Health Study Group of the Canadian Perinatal Surveillance System. JAMA 2000, 284:843-849.

25. Steketee RW, Nahlen BL, Parise ME, Menendez C: The burden of malaria in pregnancy in malaria-endemic areas. Am J Trop Med Hyg 200I, 64(I-2 Suppl):28-35.

26. Leke RF, Djokam RR, Mbu R, Leke RJ, Fogako J, Megnekou R, Metenou S, Sama G, Zhou Y, Cadigan T, Parra M, Taylor DW: Detection of the Plasmodium falciparum antigen histidine-rich protein 2 in blood of pregnant women: implications for diagnosing placental malaria. J Clin Microbiol 1999, 37:2992-2996.

27. Mayengue PI, Rieth H, Khattab A, Issifou S, Kremsner PG, Klinkert MQ, Ntoumi F: Submicroscopic Plasmodium falciparum infections and multiplicity of infection in matched peripheral, placental and umbilical cord blood samples from Gabonese women. Trop Med Int Health 2004, 9:949-958.

28. Rogerson SJ, Mkundika P, Kanjala MK: Diagnosis of Plasmodium falciparum malaria at delivery: comparison of blood film preparation methods and of blood films with histology. J Clin Microbiol 2003, 41: I370-1374.

29. Bulmer JN, Rasheed FN, Francis N, Morrison L, Greenwood BM: Placental malaria. I. Pathological classification. Histopathology 1993, 22:21I-218.

30. McGready R, Brockman A, Cho T, Levesque MA, Tkachuk AN, Meshnick SR, Nosten F: Haemozoin as a marker of placental parasitization. Trans $R$ Soc Trop Med Hyg 2002, 96:644-646.

31. Sullivan AD, Nyirenda T, Cullinan T, Taylor T, Lau A, Meshnik SR: Placental haemozoin and malaria in pregnancy. Placenta 2000, 21:417-421.

32. Kamwendo DD, Dzinjalamala FK, Snounou G, Kanjala MC, Mhango CG, Molyneux ME, Rogerson SJ: Plasmodium falciparum : PCR detection and genotyping of isolates from peripheral, placental, and cord blood of pregnant Malawian women and their infants. Trans R Soc Trop Med Hyg 2002, 96: I 45-149.

33. Kassam SN, Nesbitt S, Hunt LP, Oster N, Soothill P, Sergi C: Pregnancy outcomes in women with or without placental malaria infection. Int J Gynaecol Obstet 2006, 93:225-232.

34. Kain KC, Kyle DE, Wongsrichanalai C, Brown AE, Webster HK, Vanijanonta S, Looareesuwan S: Qualitative and semiquantitative polymerase chain reaction to predict Plasmodium falciparum treatment failure. J Infect Dis 1994, I70:1626-1630.

35. Humar A, Ohrt C, Harrington MA, Pillai D, Kain KC: Parasight F test compared with the polymerase chain reaction and microscopy for the diagnosis of Plasmodium falciparum malaria in travelers. Am J Trop Med Hyg 1997, 56:44-48.

36. Malhotra I, Dent A, Mungai P, Muchiri E, King CL: Real-time quantitative PCR for determining the burden of Plasmodium falciparum parasites during pregnancy and infancy. J Clin Microbiol 2005, 43:3630-3635.

37. Bell DR, Wilson DW, Martin LB: False-positive results of a Plasmodium falciparum histidine-rich protein 2-detecting malaria rapid diagnostic test due to high sensitivity in a community with fluctuating low parasite density. Am J Trop Med Hyg 2005, 73:199-203.

38. Scholl TO, Hediger ML, Fischer RL, Shearer JW: Anemia vs iron deficiency: increased risk of preterm delivery in a prospective study. Am J Clin Nutr 1992, 55:985-988.

39. Sarr D, Marrama L, Gaye A, Dangou JM, Niang M, Mercereau-Puijalon $O$, Lehesran JY, Jambou R: High prevalence of placental malaria and low birth weight in Sahelian periurban area. Am J Trop Med Hyg 2006, 75: I7I-I77.

40. Moormann AM, Sullivan AD, Rochford RA, Chensue SW, Bock PJ, Nyirenda T, Meshnick SR: Malaria and pregnancy: placental cytokine expression and its relationship to intrauterine growth retardation. J Infect Dis 1999, 180:1987-1993.

41. Casals-Pascual C, Kai O, Cheung JO, Williams S, Lowe B, Nyanoti M, Williams TN, Maitland K, Molyneux M, Newton CR, Peshu N, Watt SM, Roberts D: Suppression of erythropoiesis in malarial anemia is associated with hemozoin in vitro and in vivo. Blood 2006, 108:2569-2577.

42. Tako EA, Zhou A, Lohoue J, Leke R, Taylor DW, Leke RF: Risk factors for placental malaria and its effect on pregnancy outcome in Yaounde, Cameroon. Am J Trop Med Hyg 2005, 72:236-242.

43. Brocklehurst $P$, French $R$ : The association between maternal HIV infection and perinatal outcome: a systematic review of 
the literature and meta-analysis. Br J Obstet Gynaecol 1998, 105:836-848.

44. Ashdown-Lambert JR: A review of low birth weight: predictors, precursors and morbidity outcomes. I R Soc Health 2005, 125:76-83.

45. Mockenhaupt FP, Hamann L, von Gaertner C, Bedu-Addo G, von Kleinsorgen C, Schumann RR, Bienzle U: Common polymorphisms of Toll-Like receptors 4 and 9 are associated with the clinical manifestation of malaria during pregnancy. J Infect Dis 2006, 194: 184-188.

46. Ghana Aids Commission: HIV Sentinel Surveillance Report 2005. [http://www.ghanaids.gov.gh/main/publications.asp].

47. Lone FW, Qureshi RN, Emanuel F: Maternal anaemia and its impact on perinatal outcome. Trop Med Int Health 2004, 9:486-490

Publish with Bio Med Central and every scientist can read your work free of charge

"BioMed Central will be the most significant development for disseminating the results of biomedical research in our lifetime. "

Sir Paul Nurse, Cancer Research UK

Your research papers will be:

- available free of charge to the entire biomedical community

- peer reviewed and published immediately upon acceptance

- cited in PubMed and archived on PubMed Central

- yours - you keep the copyright

Submit your manuscript here:

http://www.biomedcentral.com/info/publishing_adv.asp
BiolMedcentral 